\title{
ACTIVITY DOMINANT OF PRACTICE-ORIENTED PREPARATION OF FUTURE PRIMARY SCHOOL TEACHERS FOR THE ORGANIZATION OF INTERACTIVE EDUCATIONAL INTERACTION OF STUDENTS
}

\section{ДІЯЛЬНІСНА ДОМІНАНТА ПРАКТИКО-ОРІЄНТОВАНОЇ ПІДГОТОВКИ МАЙБУТНІХ УЧИТЕЛІВ ПОЧАТКОВОЇ ШКОЛИ ДО ОРГАНІЗАЦІЇ ІНТЕРАКТИВНОЇ НАВЧАЛЬНОЇ ВЗАЄМОДІЇ УЧНІВ}

\author{
Kristina PETRYK, \\ Candidate of Pedagogical Science, \\ Senior Lecturer \\ pertykk1510@ukr.net \\ Крістіна ПЕТРИК, \\ кандидат педагогічних наук, \\ старший викладач \\ https://orcid.org/0000-0003-0615-5217 \\ Berdiansk State Pedagogical \\ Бердянський державний \\ University, \\ 4, Schmidta St., Berdiansk, \\ Zaporizhzhia region, 71100 \\ педагогічний університет, \\ $\triangle$ вул. Шмідта, 4, м. Бердянськ, \\ Original manuscript received: December 03, 2021 \\ Revised manuscript accepted: December 24, 2021
}

\begin{abstract}
In the article reveals the features of the activity dominant of practice-oriented of preparation of future primary school teachers for organization of interactive educational interaction of students and highlights its effective components: the creation of a student-centered environment in the process of preparation of future primary school teachers for organization of interactive educational interaction of students (overcoming the inertia of thinking, moving to a new level of building relationships between participants in the educational process, in particular providing a pedagogical partnership in systems "teacher-student» and "student-student» based on a dialogue where participants interact as active subjects); the focus of the teacher's activity on the practical-oriented nature of preparing students for organization of interactive educational interaction of students (activation of creative and personal potential of future teachers, modeling of practice-oriented situations in the process of didactic-methodological preparation and learning to solve them through faculties); involvement of applicants for higher education in reflexive activity during their preparation for organization of interactive educational interaction of younger students (stimulating students to self-determination and formation of personal «self-concept»; systematic implementation of pedagogical reflection of their own actions in the context of the problem under study).

It is determined that the quality of vocational education largely depends on the directions and ways to improve the practice-oriented training of higher education seekers, which is based on the introduction of interactive forms and methods of teaching. The expediency is substantiated of creating a system of interactive professional tasks in the process of preparation of future primary school teachers.

The author notes that there is a change in the functions of the teacher, in particular, actively implementing innovative technologies; a new type of pedagogical thinking is
\end{abstract}


formed, which is based on practice-oriented learning of students, the ability to create a comfortable student-centered environment. In modern realities, special importance is attached to the mobility of students, their choice of individual learning trajectory, the ability to carry out personal and professional reflection, the pursuit of self-improvement.

Key words: practice-oriented preparing of future primary school teachers, activity dominant, interactive-professional tasks, partnership pedagogy, studentcentered educational environment, reflective activity.

Вступ. Швидкі зміни, які відбуваються в суспільстві, технологіях, знаннях, вимагають від фахівців здатності до пристосування, опанування нових навичок, професій, креативності. Заклади вищої освіти $€$ фолагманами інноваційної діяльності. Перед ними постає завдання поєднання розвитку таких здібностей у студентів та одночасного надання їм спеціалізованих компетенцій у рамках обраної професії, що в майбутньому сприятиме безперервній освіті наступних поколінь. Широкомасштабний розвиток педагогіки співпраці, оновлення змісту освіти, створення власних онлайн-платформ для поширення знань, активізація та індивідуалізація навчання змінили роль і місце викладача в освітньому процесі, що актуалізує потребу в розробці сучасних технологій роботи зі студентами в закладах вищої освіти.

Якість професійної освіти значною мірою залежить від напрямків та шляхів удосконалення практико-орієнтованої підготовки здобувачів вищої освіти, в основі якої $€$ впровадження інтерактивних форм і методів навчання.

Проблему професійної підготовки майбутніх учителів початкової школи до організації інтерактивної навчальної взаємодії учнів різноаспектно розкрито в наукових дослідженнях, а саме: теоретикопрактичні засади оновлення вищої педагогічної освіти в умовах євроінтеграції (К. Баханов, І. Богданов, І. Глазкова, О. Гуренко, В. Жигірь, А. Крамаренко, Л. Петухова, І. Соколова, О. Співаковський та ін.); особливості суб'єкт-суб'єктної педагогічної взаємодії викладачів і студентів (І. Андрощук, А. Бойко, Л. Велитченко, В. Гриньова, Н. Кічук, О.Легун та ін.), зокрема майбутніх учителів початкової школи (В. Бондар, О. Кіліченко, Л. Коваль, О. Ліннік, О. Матвієнко та ін.); реформування початкової освіти на ідеях Концепції Нової української школи (І. Барбашова, Н. Бібік, М. Вашуленко, Я. Кодлюк, О. Онопрієнко, О. Савченко, С. Скворцова, А. Цимбалару та ін.); застосування практико-орієнтованих інтерактивних технологій навчання в освітньому процесі початкової школи (Л. Бєкірова, О. Комар, О. Ліба, І. Осадченко, Н. Павленко, Л. Пироженко, О. Пометун, Н. Руденко, Ю. Руднік та ін.).

Так, в умовах сьогодення особливого значення набуває пріоритетність діяльнісного підходу в процесі професійної підготовки майбутніх учителів початкової школи до організації інтерактивної навчальної взаємодії учнів.

Мета статті - розкрити особливості діяльнісної домінанти практикоорієнтованої підготовки майбутніх учителів початкової школи до організації інтерактивної навчальної взаємодії учнів та висвітлити ї̈ дієві складники. 
Методи та методики дослідження. Для реалізації мети застосовувалися методи дослідження: аналіз психолого-педагогічної літератури, синтез, систематизація, порівняння та узагальнення для уточнення змісту конструкту «діяльнісна домінанта практикоорієнтованої підготовки майбутніх учителів початкової школи»; педагогічне спостереження та конструювання інтерактивно-фахових завдань для висвітлення проблеми дослідження.

Результати та дискусії. Ефективним складником якісної практико-орієнтованої підготовки майбутніх учителів початкової школи до організації інтерактивної навчальної взаємодії учнів є створення студентоцентрованого освітнього середовища.

Основними завданнями такої системи навчання $€$ подолання інертності мислення, перехід на якісно новий рівень побудови взаємовідносин між учасниками освітнього процесу, зокрема забезпечення педагогічного партнерства в системах «викладачстудент» та «студент-студент» на основі діалогу, де вони виступають у ролі активних суб'єктів.

Сучасне розуміння інтерактивної навчальної взаємодії, як стверджує О. Комар, ґрунтується на узгодженості суб'єктної діяльності учасників освітнього процесу, під якою розуміється рівність позицій учителя та учнів (викладача і студентів). Дослідниця вважає за доцільне виділити основні вимоги щодо організації означеного процесу: суб'єктність як визнання за особистістю прав на унікальність, внутрішню свободу, активність та духовність, що базується на основі врахування інтересів учасників освітнього процесу, пріоритетів особистісноорієнтованих технологій (Комар, 2018: 142).

Суттєвою особливістю освітнього процесу в закладах вищої освіти є взаємодія викладача і студентів - об'єктивний цілеспрямований процес, який визначається цілями навчання і $€$ по суті суб'єктсуб'єктною ціннісно-змістовною діалоговою взаємодією. Визначальним чинником при цьому $є$ гуманістична спрямованість професійної діяльності, яка зумовлюється особливостями особистості викладача, позицією у стосунках зі студентами, характером взаємодії під час проведення лекційних, семінарських і практичних занять, індивідуальногуманістичним підходом до кожного студента (Коваль, Петрик, 2021).

Зауважимо, що процес професійного самовизначення й особистісного становлення майбутніх учителів початкової школи не уявляється поза освітнім середовищем, спрямованим на оволодіння професійною діяльністю. Під час підготовки майбутніх учителів початкової школи до організації інтерактивної навчальної взаємодії учнів таке середовище формують діалогічні відносини, що виникають не тільки між викладачем і студентами, але й між самими студентами - це спілкування, у якому вони усвідомлюють себе суб'єктами спільної діяльності.

Важлива роль у студентоцентрованому освітньому середовищі відводиться викладачу, який виступає посередником, «модератором» між студентами та навчальним матеріалом, готовим навчити усвідомити й 
осмислити власний потенціал, визначити мету саморозвитку й ефективно використовувати іï на практиці в швидкозмінюваному освітньому середовищі початкової школи (Коваль, Попова, Нестеренко, 2020).

На необхідності створення психоемоційного комфорту та ситуацій успіху як передумов здоров'язберігаючого середовища навчання студентів у закладах вищої освіти, як наголошує А. Крамаренко. На її думку, ситуація успіху виникає тоді, коли позитивні емоційні переживання збігаються 3 очікуваннями студента або перевершують їх, що стимулює мотивацію діяльності, прагнення стати кращим, змінюючи ставлення до майбутньої професії й свого місця в ній (Kramarenko, 2021: 473).

Створення ситуації успіху, як переконує О. Кіліченко, можливе за умови організації інтерактивної навчальної взаємодії, співтворчості й толерантності в діалоговому спілкуванні та взаємодії викладача і студентів (Кіліченко, 2017: 16).

На підставі викладеного вище зазначаємо, що створення студентоцентрованого середовища в процесі підготовки майбутніх учителів початкової школи до організації інтерактивної навчальної взаємодії учнів відбувається завдяки співпраці, творчій діалоговій взаємодії, оскільки сутність діалогу полягає у визнанні унікальності кожного партнера, особистісному захопленні, довірі, щирості вираження почуттів тощо. Назване сприяє активізації внутрішньої позитивної мотивації майбутніх учителів початкової школи до кращого розуміння себе та інших, створення активно-творчої та осмисленої інтерактивної навчальної взаємодії молодших школярів.

Спрямованість діяльності викладача на практико-орієнтований характер підготовки студентів до організації інтерактивної навчальної взаємодії учнів має на меті розвиток нового типу педагогічного мислення - це важлива характеристика особистості, яка дозволяє їй відповідати викликам часу та забезпечує можливість відходити від шаблону, встановлювати причиново-наслідкові зв'язки і відношення між різноманітними педагогічними явищами, бачити нестандартні способи розв'язання проблем, які допомагають орієнтуватися в незнайомих умовах, обґрунтовувати свої судження, робити узагальнені висновки.

Практико-орієнтоване навчання ґрунтується на квазіпрофесійній діяльності студентів. Науковці А. Вербицький, І. Гавриш, О. Демченко, В. Желанова, Л. Коваль, Л. Красюк, Т. Ніконенко, І. Осадченко, Л. Петухова, С. Скворцова та ін. стверджують, що вона реалізується шляхом переходу від власне навчальної (в формі лекцій) через навчально-професійну (інтерактивні форми організації освітнього процесу, які передбачають створення педагогічних ситуацій, у нашому випадку - практико-орієнтованих; виробнича (стажистська) практика та ін.) до власне професійної (Ніконенко, 2020: 150).

На всіх етапах педагогічного експерименту нами спеціально моделювались практико-орієнтовані ситуації, які розв'язувалися за 
допомогою системи інтерактивно-фахових завдань, представлені двома групами (дидактичні та методичні) (табл. 1).

Дидактичні інтерактивно-фрахові завдання пропонувалися майбутнім учителям початкової школи 3 метою усвідомлення особливостей професійної діяльності в умовах Нової української школи, значущості вмінь організовувати інтерактивну навчальну взаємодію учнів, побудовану на засадах дитиноцентризму, гуманізму, толерантності, партнерства та співпраці.

Методичні інтерактивно-фахові завдання виконувалися студентами для оволодіння спочатку уміннями здійснювати мікровикладання на основі суб'єкт-суб'єктної взаємодії учнів, а потім здатністю моделювати, проводити та аналізувати уроки, організовуючи інтерактивну навчальну взаємодію молодших школярів, i спрямовувалися на професійне зростання творчого потенціалу майбутніх педагогів.

Таблиця 1

Система інтерактивно-фрахових завдань

\begin{tabular}{|c|c|}
\hline Вид завдання та його зміст & Функціональне призначення завдання \\
\hline \multicolumn{2}{|r|}{ І. Дидактичні завдання } \\
\hline $\begin{array}{l}\text { 1. Завдання на засвоєння } \\
\text { теоретичних засад організації } \\
\text { інтерактивної } \\
\text { взаємодії учнів. }\end{array}$ & 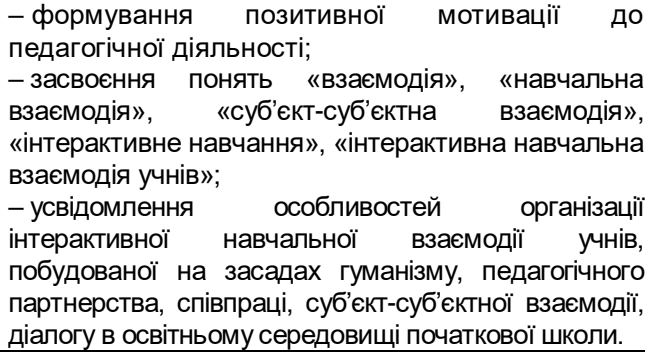 \\
\hline & Методичні завдання \\
\hline $\begin{array}{lr}\text { 1. Формування } & \text { методичної } \\
\text { компетентності } & 3 \text { фахових } \\
\text { дисциплін. } & \end{array}$ & $\begin{array}{l}\text { - уміння здійснювати мікровикладання на основі } \\
\text { організації інтерактивної навчальної взаємодії } \\
\text { учнів; } \\
\text { - здатність моделювати й проводити уроки, } \\
\text { організовуючи інтерактивну навчальну взаємодію } \\
\text { молодших школярів, та здійснювати аналіз такої } \\
\text { діяльності; } \\
\text { - розвиток нового типу педагогічного мислення. }\end{array}$ \\
\hline $\begin{array}{l}\text { 2. Розвиток } \\
\text { рефрлексії. }\end{array}$ & $\begin{array}{l}\text { - уміння аналізувати урок на основі організації } \\
\text { інтерактивної навчальної взаємодії учнів; } \\
\text { - визначення шляхів саморозвитку та } \\
\text { самовдосконалення в контексті реформування } \\
\text { початкової освіти. }\end{array}$ \\
\hline
\end{tabular}

Ці завдання носять практико-орієнтований характер, адже в їх змісті закладено моделювання контексту майбутньої професійної діяльності. 
Розв'язання інтерактивно-фрахових завдань сприяє формуванню таких якостей майбутнього педагога, як самостійність, допитливість, наполегливість у досягненні мети, усвідомленню значущості організації інтерактивної навчальної взаємодії учнів у психологічно-комфортному освітньому середовищі початкової школи, яка базується на засадах педагогіки партнерства та співпраці; оволодінню здатністю здійснювати планування та проведення уроків з урахуванням предметної специфіки; прагнути до профресійного зростання та самовдосконалення.

Запропонована нами система інтерактивно-фрахових завдань активно використовувалася під час упровадження інноваційних форм організації освітнього процесу та методів навчання: лекції (бінарна лекція, лекція-діалог, лекція-дискусія, лекція-дебати, проблемнодослідна лекція контекстного типу та ін.), практичні заняття (тренінг, баркемп, вебінари), а також виробнича (стажистська) практика, що, на наш погляд, створювало атмосфреру інтелектуальної співтворчості викладачів і студентів, забезпечувало комфортні умови навчання майбутніх педагогів, сприяло розв'язанню проблем інтерактивної навчальної взаємодії у власній педагогічній діяльності.

Спрямованість діяльності викладача на практико-орієнтований характер підготовки здобувачів вищої освіти до організації інтерактивної навчальної взаємодії учнів реалізовувалася через розв'язання інтерактивно-фрахових завдань, а застосування інноваційних форм i методів навчання сприяло посиленню мотивації студентів, що дозволило ефективно впливати на формування їх готовності до організації інтерактивної навчальної взаємодії учнів на всіх етапах експериментального навчання.

Особливого значення у процесі практико-орієнтовної підготовки майбутніх учителів початкової школи набуває рефлексія педагогічної діяльності, яка $€$ основним механізмом усвідомлення особистісних досягнень як викладача, так і студентів закладів вищої освіти. Здатність до рефрлексивної діяльності проявляється в індивідуальному стилі професійної діяльності, оцінці адекватності обраної стратегії, корекції педагогічного процесу та полягає в постійному аналізі практикоорієнтованих ситуацій, розумінні контексту як власних дій, так і дій іншої людини тощо. Тому доцільним є залучення здобувачів вищої освіти до рефлексивної діяльності під час їх підготовки до організації інтерактивної навчальної взаємодії молодших школярів, що дозволить визначити досконалість їхньої професійної підготовки.

Особливий інтерес останнім часом викликає феномен саме професійної рефрлексії, її місце в різних видах педагогічного мислення й діяльності та взаємозв'язок із професійним самовизначенням i майстерністю фрахівців, у тому числі майбутніх учителів початкової школи. Організація інтерактивної навчальної взаємодії в освітньому процесі закладу вищої освіти тісно пов'язана з розвитком у студентів рефрлексивних умінь, які дозволяють їм усвідомити значущість досвіду, 
набутого у процесі навчально-професійної діяльності, а також визначити рівень готовності до подальшої комунікативної взаємодії.

У своїх наукових доробках М. Марусинець зазначає, що саме професійна рефлексія забезпечує спроможність усвідомлювати власну діяльність, допомагає особистості визначити свої досягнення чи помилки, оцінювати можливості. За її твердженням, здатність до рефлексії значною мірою впливає на процес розвитку й фахового самовдосконалення і викладачів, і студентів та яскраво проявляється у готовності діяти в ситуаціях з високим рівнем невизначеності, гнучкості в прийнятті рішень, прагненні до реалізації нововведень та інновацій, постійному пошуку нових, нестандартних шляхів розв'язання професійних завдань, здатності переосмислювати свій професійний і особистісний досвід (Марусинець, 2015: 198).

Важливим особистісним чинником професійного зростання майбутнього фахівця, на думку Л. Коваль, є здатність до самоосвіти, саморозвитку, рефлексії, створення нового не тільки в навколишньому світі, а й у собі. Тому під час навчання в закладах вищої освіти має формуватися внутрішня потреба і здатність навчатися впродовж життя. Випускник має бути конкурентоспроможним в європейському освітньому просторі, адже саме рефлексія активно впливає на продукування інноваційних ідей (Коваль, 2021: 158).

У контексті зазначеного дослідниця підкреслює, що забезпечення з боку викладача педагогічної підтримки постійного усвідомленого суб'єктного включення кожного студента у процес фахової підготовки є тим основним чинником, що сприяє ефективному розгортанню інтерактивної навчальної взаємодії, а також розумінню ним важливості цього суб'єктного включення як вимоги сьогодення (Коваль, 2021: 159).

Підґрунтям для рефлексивного оцінювання власних досягнень студентами, за переконанням Н. Кічук, є розвиток в них здатності діяти на засадах педагогіки партнерства, що сприятиме, зокрема, формуванню в них умінь аргументувати власну думку, генерувати нові ідеї, розуміти комунікативних партнерів тощо. Існування зв'язку між розвитком рефлексивних умінь та суб'єктністю кожного студента зумовлено також тим, що засоби залучення до рефлексивних механізмів діяльності є суто індивідуальними для кожного й повинні враховувати як особистісні якості, так і рівень навчальної підготовки (Кічук, 2019: 17].

Залучення здобувачів вищої освіти до рефлексивної діяльності під час їх практико-орієнтованої підготовки до організації інтерактивної навчальної взаємодії молодших школярів в освітньому процесі закладів вищої освіти є вимогою сьогодення. Саме цей вид діяльності виступає гарантом позитивних міжособистісних контактів, а його підґрунтям $€$ розвиток у студентів здатності створювати такі партнерські взаємовідносини (між учителем початкової школи та молодшими школярами, їх батьками, колегами), які будуть сприяти формуванню в них умінь аргументовано відстоювати власні погляди, генерувати нові ідеї, володіти емоціями, розуміти своїх партнерів по комунікації тощо. 
Висновки. Отже, спрямованість діяльності викладача на практико-орієнтований характер підготовки студентів до організації інтерактивної навчальної взаємодії учнів, де основними завданнями стає моделювання і розв'язання інтерактивно-фрахових завдань займає центральну позицію. Визначені складові якісної практико-орієнтованої підготовки майбутніх учителів початкової школи до організації інтерактивної навчальної взаємодії учнів $є$ єдиним комплексом оптимальних організаційних і педагогічних фракторів, спроможних поліпшити освітній процес закладу вищої освіти, сприяти всебічному розвитку особистості студентів, їх пізнавальній активності, спрямувати майбутніх учителів початкової школи до подальших педагогічних пошуків у контексті професійної підготовки.

\section{Література}

Кіліченко О.І. Формування професійної мобільності майбутніх учителів шляхом розв'язування навчальних ситуацій / О. І. Кіліченко // Імідж сучасного педагога. - 2017. - № 3. - С. 15-19.

Кічук Н. Підготовленість фрахівця до професійної рефллексії у діяльності як параметр його конкурентоздатності / Н. Кічук // Науковий вісник Південноукраїнського національного педагогічного університету імені К. Д. Ушинського. Педагогічні науки. - Одеса, 2019. - Вип. 3 (128). - С. 15-19.

Коваль Л.В. Європейський вектор стратегічних змін у професійній підготовці майбутніх учителів початкової школи / Л. В. Коваль // Педагогіка формування творчої особистості у вищій і загальноосвітній школах: зб. наук. пр. / [редкол.: А. В. Сущенко (голов. ред.) та ін.]. - Запоріжжя : КПУ, 2021. - Вип. 76. T. 1. - C. $158-161$.

Коваль Л., Петрик К. Інтерактивна навчальна взаємодія в координатах розвитку професійної підготовки майбутніх учителів початкової школи : [монографія] / Л. Коваль, К. Петрик. - Мелітополь : Видавничий будинок Мелітопольської міської друкарні, 2021. - 266 с.

Коваль Л., Попова О., Нестеренко М. Трансформаційні зміни в професійній підготовці майбутніх педагогів у контексті впровадження ідей Концепції Нової української школи / Л. Коваль, О. Попова, М. Нестеренко // Наукові записки Бердянського державного педагогічного університету. Серія: Педагогічні науки: зб. наук. пр. Бердянськ: БДПУ, 2020. - Вип. 1. - С. 304-312.

Комар О.А. Сутність інтерактивної технології у професійній підготовці майбутніх учителів початкової школи / О.А. Комар // Науковий вісник Мукачівського державного університету. Серія : Педагогіка та психологія. 2018. - Вип. 1. - С. 140-142.

Марусинець М. М. Педагогічні умови та засоби формування професійної рефрлексії майбутніх учителів початкових класів / М. М. Марусинець // Гірська школа українських Карпат: ДВНЗ «Прикарпатський національний університет імені Василя Стефаника» : наукове фахове видання з педагогічних наук. - ІваноФранківськ, 2015. - № 12-13. - С. 196-199.

Ніконенко Т. В. Практико-орієнтована підготовка майбутніх учителів початкової школи / Т. В. Ніконенко // Педагогіка формування творчої особистості у вищій і загальноосвітній школах: зб. наук. пр. / [редкол.: А. В. Сущенко (гол. ред.) та ін.]. - Запоріжжя: КПУ, 2020. - Вип. 70. - Т. 3. - С. 147-154.

Chuchalina Y. M., Kramarenko A. N., Komar O. A., Torchynska T. A., Shevchuk I. V. Agile approach in training future primary school teachers for resolving 
complex pedagogical situation / Y. M. Chuchalina, A. N. Kramarenko, O. A. Komar, T. A. Torchynska, I. V. Shevchuk // International Electronic Journal of Elementary Education. March 2021. - Volume 13. - Issue 4. - pp. 469-477.

\section{References}

Kilichenko, O. I. (2017) Formuvannya profesijnoyi mobilnosti majbutnix uchy 'teliv shlyaxom rozv'yazuvannya navchal'ny 'x sy 'tuacij [Formation of professional mobility of future teachers by solving learning situations]. Imidzh suchasnogo pedagoga. № 3. S. 15-19. [in Ukrainian].

Kichuk, N. (2019) Pidgotovlenist faxivcya do profesijnoyi refleksiyi u diyal'nosti yak parametr jogo konkurentozdatnosti [Readiness of a specialist for professional reflection in activity as a parameter of his competitiveness]. Naukovy j visny`k Pivdennoukrayins`kogo nacional'nogo pedagogichnogo universy`tetu imeni K. D. Ushy`ns`kogo. Pedagogichni nauky`. Odesa. 3 (128), 15-19. [in Ukrainian].

Koval', L. V. (2021) Yevropejs'ky`j vektor strategichny`x zmin u profesijnij pidgotovci majbutnix uchy teliv pochatkovoyi shkoly' [European vector of strategic changes in professional training of future primary school teachers]. Pedagogika formuvannya tvorchoyi osoby`stosti u vy`shhij i zagal'noosvitnij shkolax: zb. nauk. pr. / [redkol.: A. V. Sushhenko (golov. red.) ta in.]. Zaporizhzhya : KPU. 76. T. 1, 158-161. [in Ukrainian].

Koval', L., Petry`k, K. (2021) Interakty`vna navchal'na vzayemodiya $v$ koordy'natax rozvy'tku profesijnoyi pidgotovky' majbutnix uchy`teliv pochatkovoyi shkoly' : monografiya [Interactive educational interaction in the coordinates of professional development of future primary school teachers]. Melitopol : Vy’davny`chy`j budy nok Melitopol`s`koyi mis`koyi drukarni, 266 s. [in Ukrainian].

Koval', L., Popova, O., Nesterenko, M. (2020) Transformacijni zminy` $v$ profesijnij pidgotovci majbutnix pedagogiv u konteksti vprovadzhennya idej Koncepciyi Novoyi ukrayins 'koyi shkoly ' [Transformational changes in the professional training of future teachers in the context of implementing the ideas of the Concept of the New Ukrainian School]. Naukovi zapy`sky` Berdyans`kogo derzhavnogo pedagogichnogo universy`tetu. Seriya: Pedagogichni nauky`: zb. nauk. pr. Berdyans`k: BDPU. Vy`p. 1. S. 304-312. [in Ukrainian].

Komar, O. A. (2018) Sutnist` interakty `vnoyi texnologiyi u profesijnij pidgotovci majbutnix uchy 'teliv pochatkovoyi shkoly' [The essence of interactive technology in the professional training of future primary school teachers]. Naukovy j visny`k Mukachivs`kogo derzhavnogo universy`tetu. Seriya : Pedagogika ta psy`xologiya, 1, 140-142. [in Ukrainian].

Marusy`necz', M. M. (2015) Pedagogichni umovy` ta zasoby` formuvannya profesijnoyi refleksiyi majbutnix uchy teliv pochatkovy ‘ k klasiv [Pedagogical conditions and means of forming professional reflection of future primary school teachers]. Girs`ka shkola ukrayins`ky`x Karpat: DVNZ «Pry`karpats`ky`j nacional’ny`j universy`tet imeni Vasy'lya Stefany'ka» : naukove faxove vy'dannya z pedagogichny`x nauk. Ivano-Frankivs`k, 12-13, 196-199. [in Ukrainian].

Nikonenko, T. V. (2020) Prakty ko-oriyentovana pidgotovka majbutnix uchy 'teliv pochatkovoyi shkoly' [Practical-oriented training of future primary school teachers]. Pedagogika formuvannya tvorchoyi osoby`stosti u vy`shhij i zagal’noosvitnij shkolax: zb. nauk. pr. / [redkol.: A. V. Sushhenko (gol. red.) ta in.]. Zaporizhzhya: KPU. 70. T. 3. 147-154. [in Ukrainian].

Chuchalina Y. M., Kramarenko A. N., Komar O. A., Torchynska T. A., Shevchuk I. V. Agile approach in training future primary school teachers for resolving complex pedagogical situation. International Electronic Journal of Elementary Education. March 2021. Volume 13. Issue 4. pp. 469-477. [in English]. 


\section{АНОТАЦІЯ}

У статті розкрито особливості діяльнісної домінанти практикоорієнтованої підготовки майбутніх учителів початкової школи до організації інтерактивної навчальної взаємодії учнів та висвітлено їі дієві складові: створення студентоцентрованого освітнього середовища в процесі підготовки майбутніх учителів початкової школи до організації інтерактивної навчальної взаємодії учнів (подолання інертності мислення, перехід на якісно новий рівень побудови взаємовідносин між учасниками освітнього процесу, зокрема забезпечення педагогічного партнерства в системах "викладачстудент» та "студент-студент» на основі діалогу, де учасники взаємодії виступають у ролі активних суб'єктів); спрямованість діяльності викладача на практико-орієнтований характер підготовки студентів до організації інтерактивної навчальної взаємодії учнів (активізація творчого та особистісного потенціалу майбутніх педагогів, моделювання практикоорієнтованих ситуацій у процесі дидактико-методичної підготовки та навчання розв'язувати їх за допомогою інтерактивно-фрахових завдань); залучення здобувачів вищої освіти до рефрлексивної діяльності під час їх підготовки до організації інтерактивної навчальної взаємодії молодших школярів (стимулювання студентів до самовизначення та формування особистої "Я-концепції»; систематичне здійснення педагогічної рефрлексії власних дій у контексті досліджуваної проблеми). Визначено, що якість профресійної освіти значною мірою залежить від напрямків та шляхів удосконалення практико-орієнтованої підготовки здобувачів вищої освіти в основі якої $\epsilon$ впровадження інтерактивних фоом $i$ методів навчання. Обгрунтовано доцільність створення системи інтерактивно-фрахових завдань у прочесі профресійної підготовки майбутніх учителів початкової школи.

Авторкою зазначено, що відбувається зміна функцій діяльності викладача, зокрема активно впроваджуються інноваційні технології; формується новий тип педагогічного мислення, в основі якого є практикоорієнтоване навчання студентів, здатність створювати комфортне студентоцентроване середовище. В сучасних реаліях особливого значення надається мобільності студентів, вибору ними індивідуальної траєкторії навчання, умінню здійснювати особистісну й профресійну рефрлексію, прагненню до самовдосконалення.

Ключові слова: практико-орієнтована підготовка майбутніх учителів початкової школи, діяльнісна домінанта, інтерактивно-фрахові завдання, педагогіка партнерства, студентоцентроване освітнє середовище, рефлексивна діяльність. 